\title{
ПРАВОВИЙ СТАТУС КОМІСІЇ З ПИТАНЬ ВИЩОГО КОРПУСУ ДЕРЖАВНОЇ СЛУЖБИ
}

Панова Н. С.

у статті виокремлено детермінуючі ознаки Комісіі 3 питань вищого корпусу державної служби як суб'єкта системи управління державною службою. Обгрунтовано, що Комісія з питань вищого корпусу державної служби $\epsilon$ постійно діючим, допоміжним колегіальним органом, якого уповноважено на використання сукупності правових, організаційних, соціальних, моральних механізмів впливу на відносини, що охоплюють сферу державної служби. Визначено нормативно-правову основу функціонування Комісіі з питань вищого корпусу державної служби.

Звернуто увагу на те, що Комісія з питань вищого корпусу державної служби створюється у визначеному законом порядку з урахуванням етично-моральних установок. Метою функціонування $\epsilon$ досягнення конкретних цілей управління, а саме: забезпечення єдиної державної кадровоі політики, підвищення професіоналізму й компетентності державних службовців, підготовки державних службовців, здатних захищати права і свободи громадян, брати на себе відповідальність і проявляти ініціативність і творчість у виконанні посадових обов'язків; забезпечення прозорості й гласності в державній службі; забезпечення законності у сфері державної служби, протидії корупції тощо.

Установлено, що правовий статус Комісії з питань вищого корпусу державної служби $\epsilon$ багатоаспектною та багатоелементною категорією, яка включає окремі блоки елементів: цільовий, який проявляється в цілях, завданнях і функціях Комісії; структурно-організаційний, який проявляється в порядку формування Комісії, її організаційній структурі та способі підпорядкування; компетенчійний, який проявляється через сукупність повноважень, що реалізуються у визначеній сфері відання.

Запропоновано спростити процедуру залучення представників громадських об'єднань до складу Комісії з питань вищого корпусу державної служби шляхом спрощення вимог до них.

Ключові слова: компетенції, посади державної служби категорії «А», Комісія з питань вищого корпусу державної служби, представники громадських об'єднань, доступ до державної служби, суб'єкти призначення.

В статье выделены детерминирующие признаки Комиссии по вопросам высшего корпуса государственной службы как субъекта системы управления государственной службой. Обосновано, что Комиссия по вопросам высшего корпуса государственной службы является постоянно действующим, вспомогательным коллегиальным органом, который уполномочен на использование совокупности правовых, организационных, социальных, моральных механизмов влияния на отношения, которые охватывают сферу государственной службы. Определена нормативно-правовая основа функционирования Комиссии по вопросам высшего корпуса государственной службы.

Обращено внимание на то, что Комиссия по вопросам высшего корпуса государственной службы создается в определенном законом порядке с учетом нравственно-моральных установок. Целью функционирования явля-

Панова Н. С., 2019 ется достижение конкретных целей управления, а именно: обеспечение единой государственной кадровой политики, повышения профессионализма и компетентности государственных служащих, подготовки государственных служащих, способных защищать права и свободы граждан, брать на себя ответственность и проявлять инициативность и творчество в исполнении должностных обязанностей; обеспечение прозрачности и гласности в государственной службе; обеспечение законности в сфере государственной службы, противодействия коррупции и тому подобное.

Установлено, что правовой статус Комиссии по вопросам высшего корпуса государственной службы является многоаспектной и многоэлементной категорией, которая включает в себя отдельные блоки элементов: челевой, который проявляется в целях, задачах и функциях Комиссии; структурно-организационный, который проявляется в порядке формирования Комиссии, ее организационной структуре и образе подчинения; компетенционный, который имеет проявление по совокупности полномочий, реализуемых в определенной сфере ведения.

Предложено упростить процедуру привлечения представителей общественных объединений в состав Комиссии по вопросам высшего корпуса государственной службы путем упрощения требований к ним.

Ключевые слова: компетенции, должности государственной службы категории «А», Комиссия по вопросам высшего корпуса государственной службы, представители общественных объединений, доступ к государственной службе, субъекты назначения.

The article identifies the determinant features of the Commission on Higher Civil Service Corps as a subject of the civil service management system. It is substantiated that the Commission on Higher Civil Service Corps is a standing, auxiliary collegial body, which is empowered to use a set of legal, organizational, social and moral mechanisms to influence relations that cover the civil service. The legal basis for the functioning of the Commission on Higher Civil Service Corps is determined.

The author draws attention to the fact that the Commission on Higher Civil Service Corps is established in accordance with the procedure established by law, taking into account ethical and moral standards. The purpose is to achieve specific management goals, namely: ensuring a unified state personnel policy, providing the upgrading of professionalism and competence of civil servants, guaranteeing training for civil servants capable to protect the rights and freedoms of citizens, tio take responsibility and show the initiative and creativity in the performance of official duties; ensuring transparency and visibility in the civil service; ensuring the legitimacy of the civil service, guaranteeing the fight against corruption etc.

It is established the legal status of the Commission on Higher Civil Service Corps is a multi-faceted and multi-element category, which includes individual sets of elements: a target that involves a manifestation of the purposes, objectives and functions of the Commission; structural and organizational, which has a manifestation in the order of formation of the Commission, its organizational structure and method of subordination; a com- 
petence that is manifested through a set of powers exercised in a particular area of responsibility.

The author proposes to facilitate the procedure for involving representatives of non-governmental associations in the Commission on Higher Civil Service Corps by simplifying candidates' specification.

Key words: competencies, A-category civil service posts, Commission on Higher Civil Service Corps, representatives of of non-governmental associations, access to the civil service, entities.

Постановка проблеми та іï актуальність. Оновлення концептуальних засад державної служби відповідно до стандартів Європейського Союзу зумовлює необхідність переосмислення низки науково-теоретичних положень щодо системи управління державною службою. У зв'язку з цим актуальним $\epsilon$ дослідження правового статусу Комісії з питань вищого корпусу державної служби.

Аналіз останніх досліджень і публікацій. Окреслення місця Комісії з питань вищого корпусу державної служби в системі управління державною службою $\epsilon$ неможливим без звернення до теоретичних напрацювань вітчизняних і зарубіжних науковців. Загалом вказаною проблематикою займались такі вчені, як В.Б. Авер'янов [1], О.Ф. Андрійко [2], Л.Р. Біла-Тіунова [3], Ю.П. Битяк [4], С.В. Ківалов [5], О.М. Стець [6], О.П. Хамходера [7] і низка інших.

Мета статті - виокремити детермінуючі ознаки Комісії з питань вищого корпусу державної служби як суб'єкта системи управління державною службою.

Виклад основного матеріалу. Під суб'єктами управління державною службою прийнято розуміти сукупність спеціальних органів виконавчої влади або підрозділів державних органів, до компетенції яких належать визначення, забезпечення й реалізація правових та організаційно-процесуальних засад організації й діяльності державної служби [8]. Статтею 12 Закону України «Про державну службу» до системи управління державною службою зараховано Кабінет Міністрів України, центральний орган виконавчої влади, що забезпечує формування та реалізує державну політику у сфері державної служби, Комісію з питань вищого корпусу державної служби й відповідні конкурсні комісії, керівників державної служби, служби управління персоналом [9].

Комісія з питань вищого корпусу державної служби як суб'єкт системи управління державною службою:

1) $\epsilon$ постійно діючим органом, тобто їі діяльність здійснюється до прийняття відповідного рішення про ліквідацію;

2) $є$ допоміжним колегіальним органом (утворюється для забезпечення узгодження дій центральних і місцевих органів виконавчої влади з питань, пов'язаних із реалізацією повноважень Кабінету Міністрів України [10]), якого уповноважено на використання сукупності правових, організаційних, соціальних, моральних механізмів впливу на відносини, які охоплюють сферу державної служби;

3) створюється у визначеному законом порядку з урахуванням етично-моральних установок;

4) володіє компетенцією щодо впорядкування відносини, які охоплюють сферу державної служби;

5) має на меті досягнення конкретних цілей управління, а саме: забезпечення єдиної державної кадрової політики, підвищення професіоналізму й компетентності державних службовців, забезпечення підготовки державних службовців, здатних захищати права і свободи громадян, брати на себе відповідальність і проявляти ініціативність і творчість у виконанні посадових обов'язків; забезпечення прозорості й гласності у державній службі; забезпечення законності у сфері державної служби, протидії корупції, методичне забезпечення тощо [11];

6) нормативно-правовою основою функціонування Комісії $\epsilon$ Закони України «Про державну службу» [9], «Про запобігання корупції» [12], «Про Кабінет Міністрів України» [13]; Постанови Кабінету Міністрів України «Про затвердження Положення про Комісію з питань вищого корпусу державної служби» [14], «Про затвердження Порядку відбору представників громадських об'єднань та закладів вищої освіти, що здійснюють підготовку у сфері публічного управління та адміністрування, до складу Комісії з питань вищого корпусу державної служби» [15], «Про затвердження Порядку проведення конкурсу на зайняття посад державної служби» [16]; Регламент роботи Комісії з питань вищого корпусу державної служби [17] тощо.

Особливості інституалізації функціонування Комісії з питань вищого корпусу державної служби як суб'єкта управління державною службою виражено в правовому статусі цього органу. Не вдаючись до характеристики різноманітних підходів, які використовуються в правовій науці, звернемо увагу на доцільність використання комплексного підходу до трактування правового статусу державного органу. У дослідженні за основу взято підхід, запропонований О.І. Лавреновою [18].

Відповідно, правовий статус Комісії з питань вищого корпусу державної служби (далі - Комісія) $є$ багатоаспектною та багатоелементною категорією, яка охоплює блоки елементів: цільовий (характеризується через цілі, завдання та функції Комісії); структурно-організаційний (характеризується через порядок формування Комісії, iii організаційну структуру, підпорядкування); компетенційний (характеризується через сукупність повноважень, які реалізуються у визначеній сфері відання).

Щодо детермінант структурно-організаційного блоку правового статусу Комісії, то склад Комісії формується з представників публічних органів влади та представників громадськості. При цьому критерії, що висуваються до кандидатів, суттєво різняться.

Для частини складу жодних вимог для членства в Комісії не передбачено, а саме: для представника Верховної Ради України, визначеного комітетом Верховної Ради України, до предмета відання якого належать питання державної служби (Комітет Верховної Ради України з питань державного будівництва, регіональної політики та місцевого самоврядування, до відання якого належить, зокрема, законопроектна робота, підготовка та попередній розгляд питань з державної служби), представника, визначеного Президентом України, представника, визначеного Кабінетом Міністрів України, керівника Національного агентства з питань державної служби (далі - НАДС) за посадою або за його дорученням заступник керівника цього органу [19].

Для частини членів Комісії встановлені вимоги такого характеру:

1) до фахівця з питань управління персоналом, визначеного Кабінетом Міністрів України, висувається 
вимога щодо підтвердження його статусу, тобто особа має бути спеціалістом, професіоналом, людиною, що володіє спеціальними знаннями й навичками в галузі з питань управління персоналом;

2) до представника від закладів вищої освіти висуваються вимоги щодо статусу закладу освіти (наявність ліцензії, що підтверджує здійснення підготовки здобувачів вищої освіти за освітнім ступенем магістра, доктора філософії або доктора наук за спеціальністю «Публічне управління та адміністрування» галузі знань «Публічне управління та адміністрування» не менш як 2 роки до оголошення про відбір кандидатів до складу Комісіі) та щодо самого кандидата (наявність громадянства України; наявність вищої освіти за освітнім ступенем магістра; наявність загального стажу роботи не менше ніж сім років; відсутність членства в політичних партіях; досвід діяльності чи фахові знання у сфері державної служби або сфері управління людськими ресурсами; проходження тестування на зайняття посад державної служби категорії «А») [15];

3) до представника від громадських об'єднань висуваються вимоги щодо діяльності громадського об єднання (має діяти відповідно до Закону України «Про громадські об'єднання» та протягом не менше як 5 років до оголошення про відбір кандидатів до складу Комісії провадять діяльність у сфері розвитку державної служби або у сфері управління людськими ресурсами) та щодо самого кандидата (наявність громадянства України; наявність вищої освіти за освітнім ступенем магістра; наявність загального стажу роботи не менше семи років; відсутність членства у політичних партіях; досвід діяльності чи фахові знання у сфері державної служби або у сфері управління людськими ресурсами; проходження тестування на зайняття посад державної служби категорії «А») [15].

Для участі у відборі громадські об'єднання, заклади вищої освіти, кандидати яких відповідають установленим вимогам, надсилають на адресу електронної пошти такі документи у форматі PDF: клопотання громадського об'єднання, закладу вищої освіти щодо допуску/участі їхнього кандидата до відбору; рішення керівного органу (для громадського об'єднання), рішення вченої ради (для закладу вищої освіти) про висування кандидата для участі у відборі; копію статуту чи іншого установчого документа громадського об'єднання; копію ліцензї на провадження освітньої діяльності за освітнім ступенем магістра, доктора філософії або доктора наук за спеціальністю «Публічне управління та адміністрування» галузі знань «Публічне управління та адміністрування» (для закладу вищої освіти); резюме за формою згідно з додатком; заяву кандидата про участь у відборі із зазначенням основних мотивів щодо включення до складу Комісії; декларацію особи, уповноваженої на виконання функцій держави або місцевого самоврядування, за рік, що передує року, у якому оприлюднено оголошення про відбір кандидатів до складу Комісії (для кандидатур, поданих громадськими об'єднаннями); копію документа, що посвідчує особу та підтверджує громадянство України; документи й інші матеріали, що підтверджують досвід діяльності у сфері державної служби або у сфері управління людськими ресурсами протягом не менше як п'ять років (для кандидатур, поданих громадськими об'єднаннями).
Процедура відбору до Комісії включає такі стадії:

- підготовча стадія, на якій здійснюється утворення організаційного комітету з представників НАДС і громадської ради при НАДС для організації процедури відбору кандидатів і перевірки поданих ними документів на відповідність визначеним вимогам, оголошення про відбір кандидатів до складу Комісії та прийом документів;

- стадія добору можливих кандидатів, на якій здійснюється перевірка документів щодо відповідності встановленим вимогам; оформлення протоколу про рекомендацію кандидатів на членство в Комісії та передача його Голові НАДС не пізніше наступного дня після проведення засідання; здійснення тестування на зайняття посад державної служби категорії «А»;

- стадія прийняття рішення, на якій здійснюється оприлюднення на офіційному веб-сайті НАДС списку кандидатів, рекомендованих Кабінетові Міністрів України для включення до складу Комісії.

Щодо терміну повноважень членів Комісії, то він становить чотири роки, окрім осіб, термін повноважень яких визначається строком повноважень суб'єкта, представником якого $є$ особа в складі Комісії (Верховна Рада України, Президент України, Кабінет Міністрів України). Крім того, Голова НАДС або його заступник перебувають у складі Комісії відповідно до строку перебування на посаді.

Дострокове припинення повноважень можливе в таких випадках: подання особистої заяви про припинення повноважень члена Комісії або звільнення з посади, у зв'язку з перебуванням на якій його призначено членом Комісії; неможливість виконувати обов'язки за станом здоров'я (за наявності медичного висновку); припинення громадянства України або виїзд на постійне місце проживання за межі України; набрання законної сили обвинувальним вироком суду за вчинення умисного злочину; набрання законної сили рішенням суду про притягнення до адміністративної відповідальності за вчинення корупційного або пов'язаного $з$ корупцією правопорушення; визнання його недієздатним або обмеження його дієздатності судом; визнання його безвісно відсутнім або оголошення померлим; смерті; систематичного (два й більше разів підряд) нез'явлення без поважних причин на засідання Комісії або її комітету [14].

Умови оплати праці їі членів, крім членів Комісії, які входять до її складу за посадою, затверджуються Кабінетом Міністрів України. Станом натепер оплата праці членів Комісії здійснюється за рахунок фонду оплати праці, передбаченого кошторисом видатків НАДС. Між членом Комісії та НАДС укладається договір про виконання обов'язків члена Комісії, який діє до 31 грудня року, у якому його укладено. Оплата праці здійснюється раз на місяць на підставі акту виконаних робіт, який готується спеціальним структурним підрозділом НАДС [20].

Порядок роботи Комісії реалізується через засідання, які проводяться прозоро. Тобто щоб оголошення про їх проведення, порядок денний, протоколи таких засідань і висновки Комісії були оприлюднені на офіційному веб-сайті Кабінету Міністрів України. Прозорість проведення засідань Комісії має проявляється в тому, що засідання Комісії для представників засобів масової інформації $\epsilon$ відкритими, окрім випадків проведення закритого конкурсу на посади державної служби категорії «A». За рішенням Комісії на їі засіданні можуть 
бути присутніми представники державних органів, наукових установ, навчальних закладів, засобів масової інформації, громадських об'єднань і міжнародних організацій. Відповідне рішення приймається Комісією на основі звернення зазначених вище органів, об'єднань, установ та організацій або за пропозицією будьякого члена Комісії. При цьому важливо зазначити, що члени Комісії під час комунікації із засобами масової інформації, взаємодії з установами й організаціями, інститутами громадянського суспільства та міжнародними організаціями виступають від свого імені.

Засідання Комісії вважається повноважним, якщо в ньому бере участь не менше ніж половина членів Комісії (в окремих випадках, на письмову вимогу 4 членів Комісії - за участі третини членів Комісії). Рішення Комісії приймаються відкритим голосуванням членів Комісії шляхом підняття рук без можливості передачі голосу іншому членові Комісії. Вагомим для відображення функціонального призначення Комісії $\epsilon$ можливість утворення комітету з відбору кандидатів на відповідну посаду та комітету з дисциплінарних проваджень із розгляду відповідних питань [17].

Комітет 3 відбору кандидатів на відповідну посаду створюється з метою забезпечення виконання Комісією своїх повноважень щодо проведення конкурсу на зайняття вакантних посад державної служби категорії «А» та внесення суб'єктові призначення пропозицій щодо переможця конкурсу та другого за результатами конкурсу кандидата i $\epsilon$ робочим органом Комісії. Комітет з відбору кандидатів вивчає результати проведеної секретаріатом Комісії перевірки документів кандидатів на зайняття вакантних посад державної служби категорії «А»; аналізує інформацію з відкритих джерел щодо кандидатів, які беруть участь у конкурсі на зайняття вакантних посад державної служби категорії «A»; уносить на розгляд Комісії пропозиції щодо часу проведення окремих етапів конкурсу, змісту, часу вирішення ситуаційних завдань i їх кількості, доцільності ïх презентації кандидатами, форм бланків для заповнення кандидатами персональних даних і розв'язання ситуаційного завдання; здійснює організацію запитів щодо думки професійного середовища про особу, яка виявила бажання взяти участь у конкурсі; опрацьовує документи щодо переведення державних службовців, які займають посади державної служби категорії «А», на рівнозначну або нижчу посаду до іншого державного органу у випадках, передбачених Законом України «Про державну службу» [14].

Комітет 3 дисциплінарних проваджень 3 розгляду відповідних питань створюється з метою забезпечення виконання Комісією своїх повноважень щодо здійснення дисциплінарного провадження для визначення ступеня вини, характеру й тяжкості дисциплінарного проступку, учиненого державними службовцями, які займають посади категорії «A». Комітет з дисциплінарних проваджень попередньо опрацьовує ініційоване суб'єктом призначення питання про відкриття дисциплінарного провадження стосовно державного службовця, який займає посаду державної служби категорії «А», і вносить відповідні пропозиції Комісії для прийняття рішення. Після ухвалення рішення Комісією про відкриття дисциплінарного провадження стосовно державного службовця, який займає посаду державної служби категорії «А», комітет з дисциплінарних проваджень формує дисциплінарну справу; здійснює опрацювання відповідних матеріалів і підготовку пропозицій Комісії щодо наявності чи відсутності підстав для притягнення до відповідальності, ступеня вини, характеру й тяжкості дисциплінарного проступку, учиненого державними службовцями, які займають посади державної служби категорії «А»; готує для розгляду та схвалення Комісією проект пропозицій суб'єктові призначення про накладення на державного службовця дисциплінарного стягнення чи закриття дисциплінарного провадження. Комітет 3 дисциплінарних проваджень попередньо опрацьовує пропозиції щодо дострокового звільнення з посади за ініціативи суб'єкта призначення державних службовців, які займають посади державної служби категорії «А», та готує зазначене питання для розгляду Комісією [14].

Компетенційний блок як елемент правового статусу Комісії відображено в повноваженнях, якими ії наділено у сфері управління державною службою. Відповідно до ст. 14 Закону України «Про державну службу», на Комісію покладаються такі повноваження:

- погодження розроблених НАДС типових вимог до професійної компетентності державних службовців, які займають посади державної служби категорії «А» (при цьому Комісія не розробляє (розробляє НАДС) i не затверджує (затверджує Кабінет Міністрів України) типові вимоги, а тільки погоджує їх, тобто надає згоду на їх затвердження в установленому порядку);

- проведення конкурсу на зайняття посад державної служби категорії «А» та внесення суб'єкту призначення пропозиції щодо кандидатур на такі посади загальною кількістю не більше ніж п'ять осіб (початкова редакція цього положення передбачала, що Комісія вносить суб'єкту призначення пропозиції щодо переможця конкурсу, другого за результатами конкурсу кандидата на вакантну посаду), що розширює повноваження суб'єкта призначення щодо прийняття рішення про призначення на посаду конкретного кандидата;

- здійснення дисциплінарних проваджень щодо державних службовців, які займають посади державної служби категорії «А», та внесення суб'єктові призначення пропозицій за наслідками дисциплінарного провадження [9].

Висновки. Отже, правовий статус Комісії з питань вищого корпусу державної служби $є$ багатоаспектною та багатоелементною категорією, яка включає в себе окремі блоки елементів: цільовий, який проявляється в цілях, завданнях і функціях Комісії; структурно-організаційний, який проявляється в порядку формування Комісії, їі організаційній структурі та способі підпорядкування; компетенційний, який проявляється через сукупність повноважень, що реалізуються у визначеній сфері відання. Доцільним $\epsilon$ подальше дослідження структурних елементів правового статусу Комісії як одного із суб'єктів управління державною службою. 3 метою подолання виявлених проблем запропоновано спростити процедуру залучення представників громадських об'єднань до складу Комісії шляхом спрощення вимог до них. 


\section{Література}

1. Авер'янов В.Б. Фактори централізації та децентралізації у структурно-функціональній організації апарату державного управління. Державне управління в Україні: централізація і децентралізація. Київ, 1997. С. 103.

2. Андрійко О.Ф. Державний контроль в Україні: організаційно-правові засади : монографія. Київ : Наукова думка, 2004. 300 c.

3. Біла-Тіунова л.Р. Теоретико-правові аспекти управління державною службою в Україні. Актуальні проблеми політики : збірник наукових праць / голов. ред. С.В. Ківалов ; відп. за вип. Л.І. Кормич. Одеса : Фенікс, 2009. Вип. 38. С. 52-59.

4. Битяк Ю.П. Державна служба в Україні: організаційно-правові засади : монографія. Харків : Право, 2005. 304 с.

5. Ківалов С.В. Управління державною службою. Адміністративне право України. Академічний курс : підручник : у 2 т. / редкол.: В.Б. Авер'янов (гол.) та ін. Київ : Юрид. думка, 2007. Т. 1. С. 324-327.

6. Стець О.М. Адміністративно-правовий статус Головного управління державної служби України : автореф. дис. ... канд. юрид. наук. Одеса, 2011. 20 с.

7. Хамходера О.П. Адміністративно-правовий статус інспекції як центрального органу виконавчої влади : дис. ... канд. юрид. наук. Одеса, 2014. 237 с.

8. Балух Д.В. До визначення особливостей управління державною службою. Південноукраїнський правничий часопис. 2008. № 4. С. 123-127.

9. Про державну службу : Закон України від 10.12.2015. URL: http://zakon2.rada.gov.ua/laws/show/889-19 (дата звернення: 20.01.2020).

10. Питання консультативних, дорадчих та інших допоміжних органів, утворених Кабінетом Міністрів України : Постанова Кабінету Міністрів України від 17.06.2009. URL: https://zakon.rada.gov.ua/laws/show/599-2009-\% D0\%BF (дата звернення: 20.01.2020).

11. Гаркуша А.Т. Адміністративно-правовий статус Національного агентства України з питань державної служби : дис. .... канд. юрид. наук : 12.00.07. Одеса, 2017. 248 с.

12. Про запобігання корупції : Закон України від 14.10.2014 № 1700-VII. URL: https://zakon.rada.gov.ua/ laws/show/1700-18 (дата звернення: 20.01.2020).

13. Про Кабінет Міністрів України : Закон України від 27.02.2014 № 794-VII. URL: https://zakon.rada.gov.ua/laws/ show/794-18 (дата звернення: 20.01.2020).

14. Про затвердження Положення про Комісію 3 питань вищого корпусу державної служби : Постанова
Кабінету Міністрів України від 25.03.2016 № 243. URL: https://zakon.rada.gov.ua/laws/show/243-2016-п\#n9 (дата звернення: 20.01.2020).

15. Про затвердження Порядку відбору представників громадських об'єднань та закладів вищої освіти, що здійснюють підготовку у сфері публічного управління та адміністрування, до складу Комісії з питань вищого корпусу державної служби : Постанова Кабінету Міністрів України від 03.11.2019 № 906. URL: https://zakon.rada.gov.ua/laws/show/906-2019-п\#n11 (дата звернення: 20.01.2020).

16. Про затвердження Порядку проведення конкурсу на зайняття посад державної служби : Постанова Кабінету Міністрів України від 25.03.2016 № 246. URL: https://zakon.rada.gov.ua/laws/show/246-2016-п (дата звернення: 20.01.2020).

17. Регламент роботи Комісії з питань вищого корпусу державної служби : Рішення Комісії з питань вищого корпусу державної служби від 28.07.2016. URL: nads.gov.ua/vishchij-korpus-derzhavnoyi-sluzhbi/ komisiya-z-pitan-vishchogo-korpusu-derzhavnoyi-sluzhbi/ reglament-roboti (дата звернення: 20.01.2020).

18. Лавренова О.І. До питання адміністративно-правового статусу державної служби як центрального органу виконавчої влади. Наше право. 2012. № 4. Ч. 2. C. 67-71.

19. Про утворення Комісії з питань вищого корпусу державноїслужбитазатвердженняіїперсональногоскладу:Розпорядження Кабінету Міністрів України від 28.10.2019. URL: https: / /www.kmu.gov.ua/npas/pro-utvorennya-komisiyiz-pitan-vishchogo-korpusu-derzhavnoyi-sluzhbita-zatverdzhennya-yiyi-personalnogo-skladu-i281019 (дата звернення: 20.01.2020).

20. Про затвердження Умов оплати праці членів Коміciї з питань вищого корпусу державної служби : Постанова Кабінету Міністрів України від 24.12.2019. URL: https: / / zakon.rada.gov.ua/laws/show/1169-2019-\%D0\%BF (дата звернення: 20.01.2020).

Панова Н. С., кандидат юридичних наук, доцент кафедри конституційного, адміністративного і міжнародного права Київського інституту інтелектуальної власності і права Національного університету «Одеська юридична академія» 